Studia Anglica Posnaniensia 49/2 2014

doi: 10.2478/stap-2014-0008

\title{
ALTERNATION VS. ALLOMORPHIC VARIATION IN OLD ENGLISH WORD-FORMATION: EVIDENCE FROM THE DERIVATIONAL PARADIGM OF STRONG VERBS ${ }^{1}$
}

\author{
CARMEN NOVO URRACA AND LAURA PESQUERA FERNÁNDEZ
}

Universidad de La Rioja

\begin{abstract}
This article addresses the question of Old English alternations with a view to identifying instances of allomorphic variation attributable to the loss of motivation and the subsequent morphologization of alternations. The focus is on the strong verb and its derivatives, in such a way that the alternations in which the strong verb partakes can be predicted on the basis of phonological principles, whereas allomorphic variation with respect to the strong verb base is unpredictable. Out of 304 derivational paradigms based on strong verbs and comprising 4,853 derivatives, 478 instances have been found of phonologically motivated vocalic alternations. The conclusion is reached that the most frequent alternations are those that have /a/ as source and those with $/ \mathrm{y} / \mathrm{as}$ target, because /a/ is the point of departure of i-mutation and /y/ its point of arrival. Sixteen instances of allomorphic variation have also been found, of which /e/ /eo/, /e/ /ea/ and /i/ /e/ are relatively frequent.
\end{abstract}

Keywords: allomorphic variation, alternations, derivatives, morphology, strong verb

\section{Aims and scope}

Although the philological study of the morphology of Old English in general and its word-formation phenomena in particular have a long tradition (see Lindemann 1970 and the references provided by this author), the derivational morphology of this stage of the English language has been dealt with from a more theoretically based perspective only in relatively recent works. Two main lines have been taken. First, Kastovsky (1986, 1989, 1990, 1992, 2005, 2006) has

1 This research has been funded by the Ministry of Science and Innovation through the project FFI2012-29532. 
approached the question from the angle of the typological shift from stemformation to word-formation, as a result of which the derivation and inflection at the end of the Old English period no longer make use of variable bases but of invariable ones. ${ }^{2}$ Second, Martín Arista (2008, 2009, 2010a, 2010b, 2011a, 2011b, 2012, 2013) has explained the derivational processes of Old English within a morphology of structural-functional persuasion by proposing a syntagmatic procedure of word-formation inspired by the layered representation of clause and phrase structure adopted by functional grammars (Foley \& Van Valin 1984; Dik 1997a, 1997b; Van Valin \& LaPolla 1997; Van Valin 2005). ${ }^{3}$

Along with the analysis of the nature of morphological bases, Kastovsky (1968) has listed an inventory of alternations that can be traced back to the study of Germanic ablaut, which, in terms of word-formation, involves the use of inflectional means for derivational purposes, notably the stems of the present, preterite and past participle of strong verbs. Like the other Germanic languages, Old English has strong verbs organized in seven classes, which result from the vowel contrasts among infinitive, preterite singular, preterite plural and past participle illustrated by figure 1 :

\begin{tabular}{|c|c|c|c|c|}
\hline & Infinitive & $\begin{array}{l}\text { Preterite } \\
\text { singular }\end{array}$ & $\begin{array}{c}\text { Preterite } \\
\text { plural }\end{array}$ & $\begin{array}{c}\text { Past } \\
\text { Participle }\end{array}$ \\
\hline I & drīfan 'to drive' drāf & drifon & drifen & \\
\hline II & clèofan 'to cleave' & clēaf & clufon & clofen \\
\hline III & drincan 'to drink' & dranc & druncon & drunken \\
\hline IV & beran 'to bear' & $b æ r$ & $b \bar{x} r o n$ & boren \\
\hline V & giefan 'to give' geaf & gèafon & giefen & \\
\hline VI & standan 'to stand' & stōd & stōdon & standen \\
\hline VII & slǣpan ‘to sleep’ & slēp & slēpon & sl̄̄pen \\
\hline
\end{tabular}

Figure 1. The seven classes of Old English strong verbs

The vocalic contrasts displayed by figure 1 have been largely discussed in the literature as ablaut (or apophony) and the different vocalic value are usually referred to as ablaut grades. Lass (1994: 108) and Ringe (2006: 11) agree that normal and long grades typically appear in accented position, and zero-grades in unaccented syllables followed by an accent. Some of these ablaut grades appear in the derivatives of strong verbs. Palmgren (1904) relates the vowel of

2 This line has been pursued by Haselow (2011), who deals with the rise of analytic tendencies in English morphology and the productivity of some nominal suffixes. Cf. Trips (2008).

3 Martín Arista \& Cortés Rodríguez (forthcoming) also engage in functional morphology, but from the specific perspective of grammaticalization. 
some nominal derivatives to the present tense of strong verbs, as in feminines like dræge 'drag-net' dragan 'to drag', masculines like bēod 'table, bowl' beeodan 'to offer' and neuters like geðeot 'howling' ðeotan 'to howl'. Nominal derivatives can also present the vowel of the preterite singular, as is the case with the feminine têag 'chain' têon 'to draw', the masculine swam 'fungus'

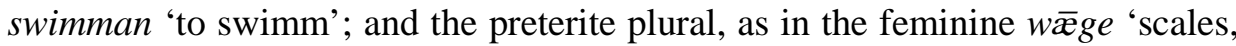
balance' wegan 'to weigh' and the neuter gestæn 'groaning' stenan 'groan'. The past participle shares its vowel with feminines like storfe 'flesh of animals that have died by disease' steorfan 'to die', masculines like blice 'laying bare (of bone through wound)' blīcan 'shine, be laid bare (of bone)' and neuters like geðwit 'what is shaved off, chip' ðwìtan 'cut, shave off'. By focusing on the morphological class of the weak verb, Schuldt (1905) finds that some weak verbs from class 1 display the vowel of the preterite singular of the strong verb ( $b \bar{x} t a n$ 'to bridle' bittan 'to bite'). Others contain the vowel of the infinitive but alternate with the vowel of the preterite (missan 'to miss, fail' miðan 'to conceal'). Regarding weak verbs of class 2, some share the vowel of the preterite singular of the strong verb (wracian 'to be in exile' wrecan 'to drive, press'). Other weak verbs from class 2 hold a quantity contrast with the past participle of the strong verb (cunnian 'to prove, try' cunnan 'to be or become acquainted with'). Finally, weak verbs of class 2 can also be derived with the vowel of the present or the preterite plural of the strong verb, as is the case with treddian 'to tread, step, walk' tredan 'to tread'. Jensen (1913) carries out a similar analysis of all major lexical classes. In the class of the adjective, he distinguishes those formed with the vowel of the present, like scin 'extraordinary appearance' scinan 'to shine' and reōd 'red' reōdan 'to redden'; with the vowel of the preterite singular, like hnāg 'bent' hniggan 'to bend down' as well as reāfol 'rapacious' reāf 'to spoil'; and with the vowel of the past participle, such as $\overline{\mathfrak{x}} s w \bar{i} c$ 'offensive' swīcan 'to move about' and flugol 'apt to fly' fleoggan 'to fly'. Given these correspondences, which ultimately point to the existence of a common morphological base, Hinderling (1967) remarks that strong verbs constitute the starting-point of lexical derivation in the Germanic languages. ${ }^{4}$ Furthermore, the regularity of alternations of vowels in roots and affixes of words that are etymologically and morphologically related has been stressed by linguists like Mailhammer (2007), who attributes to ablaut functional status in Proto-Germanic, given that it can mark grammatical contrasts such as non-past vs. past.

While the motivation of a significant part of the contrast holding between strong verbs and their derivatives is to be found in ablaut, some correspondences between the strong verb and its derivatives clearly fall out of the scope

4 Cf. García García (2012). 
of this phenomenon. In a study in the deverbal formation of nouns by means of zero derivation and the recurrent morphological constrasts that arise throughout the process, Kastovsky (1968: 59) identifies the alternations listed in figure 2. Note that $A$ stands for vocalic, $C$ for consonantal and $R$ for reverse. Phonemes are represented between strokes and allophonic variants between square brackets. PA marks a coincidence with Palmgren's (1904) analysis.

\begin{tabular}{|c|c|c|c|}
\hline A1 & $/ \mathrm{a} / \sim / \mathfrak{x} /$ & \multirow{2}{*}{\multicolumn{2}{|c|}{$\begin{array}{l}\text { faran } \sim f æ r \\
\text { stæl } \sim \text { stal }\end{array}$}} \\
\hline A1R & /æ/ /a/ & & \\
\hline A2 & /a/ /e/ & \multicolumn{2}{|c|}{ acan $\sim$ ece $(=\mathrm{PA} 1$ land $\sim$ lendan $)$} \\
\hline A2R & $/ \mathrm{e} / \sim / \mathrm{a} /$ & \multicolumn{2}{|c|}{ sendan $\sim$ sand } \\
\hline A3 & /ea/ /ie/ & \multicolumn{2}{|l|}{ feallan $\sim$ fiell } \\
\hline A3R & /ie/ /ea/ & \multicolumn{2}{|c|}{ mierran $\sim$ gemearr } \\
\hline A4a & $/ \mathrm{e} / \sim / \mathrm{i} /$ & \multicolumn{2}{|c|}{ gecweden $\sim$ cwide $(=\mathrm{PA} 3$ segl $\sim$ siglan $)$} \\
\hline A4b & /eo/ /ie/ & \multicolumn{2}{|c|}{ weorpan $\sim$ wierp } \\
\hline A4bR & /y/ /eo/ & \multicolumn{2}{|c|}{ wyrcan $\sim$ weorc } \\
\hline A5 & $/ \mathrm{o} / \sim / \mathrm{y} /$ & \multicolumn{2}{|c|}{ gebrocen $\sim$ bryce (=PA4 bold byldan $)$} \\
\hline A5R & $/ \mathrm{y} / \sim / \mathrm{o} /$ & \multicolumn{2}{|c|}{ spyrian $\sim$ spor } \\
\hline A6 & $/ \mathrm{u} / \sim / \mathrm{y} /$ & \multicolumn{2}{|c|}{ burston $\sim$ byrst (=PA6 lust $\sim$ lystan $)$} \\
\hline A6R & $/ \mathrm{y} / \sim / \mathrm{u} /$ & \multicolumn{2}{|c|}{ hyscan $\sim$ husc } \\
\hline A7 & $/ \overline{\mathrm{a}} / \sim / \overline{\mathrm{x}} /$ & \multicolumn{2}{|c|}{$d r \bar{a} f \sim d r \bar{x} f(=\mathrm{PA} 2 l \bar{a} r \sim l \bar{x} r a n)$} \\
\hline A7R & $/ \overline{\mathfrak{e}} / \sim / \overline{\mathrm{a}} /$ & \multicolumn{2}{|c|}{ lǣran-lār } \\
\hline A8 & $/ \overline{\mathrm{O}} / \sim / \overline{\mathrm{e}} /$ & \multicolumn{2}{|c|}{ lōcian $\sim$ lēc $(=\mathrm{PA} 5$ blōd $\sim$ blèdan $)$} \\
\hline A8R & $/ \overline{\mathrm{e}} / \sim / \overline{\mathrm{o}} /$ & \multicolumn{2}{|c|}{$f \bar{e} d a n \sim f o ̄ d a$} \\
\hline A9 & $/ \overline{\mathrm{e}} \mathrm{a} / \sim / \overline{\mathrm{1}} \mathrm{e} /$ & \multicolumn{2}{|c|}{ hlēat hlīet (=PA8 stēam stīeman) } \\
\hline A9R & $/ \overline{\mathrm{e}} / \sim / \overline{\mathrm{e}} \mathrm{a} /$ & \multicolumn{2}{|c|}{$\bar{\imath} e c a n \sim \bar{e} a c a$} \\
\hline A10 & $/ \overline{\mathrm{e}} \mathrm{O} / \sim / \overline{\mathrm{1}} \mathrm{e} /$ & \multicolumn{2}{|l|}{ flèotan flīeta } \\
\hline A10R & $/ \overline{1} \mathrm{e} / \sim / \overline{\mathrm{e}} \mathrm{O} /$ & \multicolumn{2}{|l|}{ stīeran stēora } \\
\hline A11 & $/ \overline{\mathrm{u}} / \sim / \overline{\mathrm{y}} /$ & \multicolumn{2}{|c|}{$b \bar{u} a n \sim b \bar{y}(=\mathrm{PA} 7$ rūm $\sim r \bar{y} m a n)$} \\
\hline C1 & \multicolumn{2}{|c|}{ [non-palatal] $\sim$ [palatal] } & acan $\sim$ ece \\
\hline C1R & \multicolumn{2}{|c|}{ [palatal] $\sim$ [non-palatal] } & pencan panc \\
\hline C2 & \multicolumn{2}{|c|}{ /short consonant/ /long consonant/ } & tredan $\sim$ tredde \\
\hline $\mathrm{C} 2 \mathrm{R}$ & \multicolumn{2}{|c|}{ /long consonant/ /short consonant/ } & sellan $\sim$ sala \\
\hline C3 & \multicolumn{2}{|c|}{$/ \mathrm{k} / \sim[\mathrm{x}]$} & t $\bar{x} c a n \sim$ getāh \\
\hline $\mathrm{C} 4$ & \multicolumn{2}{|l|}{$[\mathrm{g}] \sim / \mathrm{j} /$} & dragan $\sim$ dræge \\
\hline C4R & \multicolumn{2}{|l|}{$/ \mathrm{j} / \sim[\mathrm{g}]$} & wegan $\sim$ wegu \\
\hline C5 & \multicolumn{2}{|l|}{$[ð] \sim / \mathrm{d} /$} & $s c r \bar{a} \partial \sim s c r \bar{a} d$ \\
\hline C6 & \multicolumn{2}{|l|}{ /d/ [ð] } & scridon $\sim$ scriðe \\
\hline C7 & \multicolumn{3}{|c|}{ [voiced fricative] [voiceless fricative] } \\
\hline
\end{tabular}

Figure 2. Strong verb-noun alternations in Old English (Kastovsky 1968) 
The framework of alternations as put forward by Kastovsky (1968) constitutes a double synthesis: firstly, of contrasts motivated by ablaut and by other phenomena and, secondly, of synchronic and diachronic facts. Beginning with the motivation of the contrasts under scrutiny, some of them can be related, as has already been pointed out, to the ablaut pattern of the corresponding strong verbs, thus A1R /æ/ /a/ stæl (preterite singular of stelan) stalu; A4a /e/ /i/ cweðen (past participle of cweðan) cwide; A5 /o/ /y/ brocen (past participle of brecan) bryce; A6 /u/ /y/ burston (preterite plural of berstan) byrst; A7 / $/ \bar{a} / \sim / \overline{\mathfrak{x}} / d r \bar{a} f$

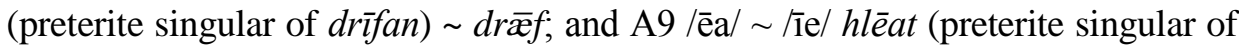
hlèotan) $\sim$ hliet. Whereas these alternations reflect ablaut patterns, most of them, like fōn 'to take' feng 'to grasp', are largely motivated by i-mutation, which is described by Hogg (1992: 113) as follows: Old English vowels harmonized to an /i/ or $/ \mathrm{j} /$ following them in the same word. This caused all back vowels to front and all short vowels (except naturally /i/) and diphthongs to rise when /i/ or /j/ followed in the next syllable. This can be represented as in figure 3:

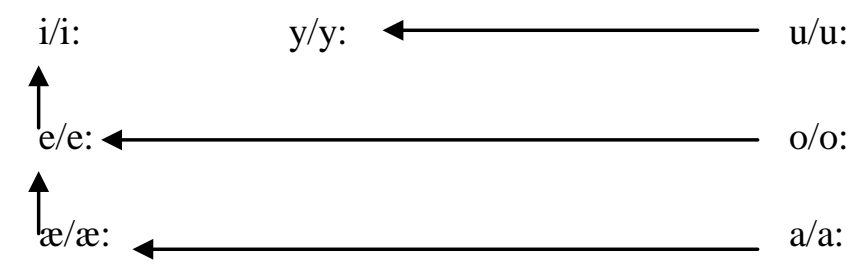

Figure 3. I-mutation in the Old English vowel system (based on Hogg 1992) ${ }^{5}$

The reverse alternations of figure 2, however, do not seem to conform to the changes grouped under i-mutation, as presented in figure 3. For instance, A1R /æ/ $\sim / a /$ stæl $\sim$ stalu apparently runs contrary to the predictions of i-mutation. However, what is at stake here is the morphological relation holding between the weak verb and the noun. Unlike strong verbs, weak verbs are mostly derived and select the noun, the adjective or a strong verb as base. That is, given hyscan and husc the verb is derived from the noun, in such a way that i-mutation mediates between base and derivative exactly as in deverbal nouns based on strong verbs.

Eventually, the phonological rules that produced ablaut were morphologized (Lass 1994; Kastovsky 2006; Ringe 2006). All the Old English alternations had originally been phonologically conditioned but they became progressively more

$5 \quad$ Campbell (1959: 71) points out that the i-mutation of diphthongs shows more variation. West-Saxon long and short/ea/ and /io/ were mutated to long and short /ie/, whereas in the other dialects long and short /ea/ were mutated to long and short /e/ and long and short /io/ were not subject to mutation. Regarding long vowels, Campbell (1959: 71-72) notes that West-Saxon $/ \overline{\mathfrak{x}} /$ and $/ \overline{\mathrm{e}} /$ in the other dialects do not undergo raising by umlaut. 
opaque and morphologically conditioned until the breakdown of the whole morphophonemic system that took place at the end of the Old English period. As Kastovsky (2006: 171) remarks:

\begin{abstract}
Towards the end of the Old English period, the language was characterized by large-scale allomorphic variation, with most of these alternations being unpredictable. This eventually led to considerable analogical levelling in the Middle English period with the result of eliminating most of these alternations (...) Stemalternation became a characteristic feature of the irregular part of inflection, whereas it disappeared from word-formation on a native basis except some unproductive cases such as long $\sim$ length.
\end{abstract}

Given this state of the art, the aim of this research is to contribute to the study of Old English word-formation from the perspective of morphological relatedness by distinguishing morphological contrasts holding between related forms that share a lexemic root from alternations proper, which represent a principled subset of morphological contrasts. The focus is on the strong verb and its derivatives, in such a way that the alternations in which it partakes can be predicted on the basis of phonological principles, whereas allomorphic variation with respect to the strong verb base does not abide by phonological principles and is unpredictable. Vocalic alternations only are analyzed because consonantal contrasts represent allophonic phenomena. Thus, this article addresses the question of the loss of motivation and the subsequent morphologization of alternations, for which Kastovsky (2006) makes no provision, apart from stating that the phenomenon takes place. It is also worth mentioning that the analysis reported in the following sections is mainly synchronic and does not restrict itself to the lexical class of nouns, as Kastovsky (1968) does, but also includes the major lexical classes of the verb (weak and strong) and the adjective.

\title{
2. Data of analysis and methodology
}

We have devised a methodology that consists of the following steps: (i) the retrieval of all records of strong verbs from the lexical database of Old English Nerthus (www.nerthusproject.com); ${ }^{6}$ (ii) the identification of all inflectional forms of strong verbs relevant for derivational morphology; (iii) the isolation of basic strong verbs; (iv) the compilation of derivational paradigms; (v) the identification of the vocalic contrasts holding in derivation; (vi) the classification of the contrasts based on ablaut; and (vii) the distinction of phonologically motivated alternations from instances of allomorphic variation.

6 We have followed the conventions of the lexical database Nerthus regarding homophones with different lexical or morphological features, which are numbered, as in a wiht 1 (noun) 'something', àwiht 2 (adverb) 'at all' and $\bar{a}$ wiht 3 (adjective) 'of value'. 
The most significant decision that underlies the methodological steps we have just described affects the role that strong verbs play in Old English lexical derivation. Strong verbs constitute the starting-point (but not the only base) of Germanic derivation. Therefore we have opted for a compromise solution that consists of analysing the derivational paradigm of strong verbs, but considers the major lexical categories in the recursive and non-recursive derivation and compounding that give rise to the derivational paradigm. By derivational paradigm we mean all the derivatives that can be derived by productive synchronic means or recovered in the diachrony, along with the base of derivation, a basic strong verb. As illustration of the concept of derivational paradigm, consider the class VI strong verb bacan 'to bake' and its derivatives äbacan (verb, strong VI) 'to bake', bæcere 1 (noun, masculine) 'baker', bæcering (noun, masculine) 'gridiron' and bæcestre (noun, feminine) 'female baker', all of which are morphologically and semantically related to the strong verb.

From a quantitative perspective this work has analysed 29,937 lexemes (type) beginning with the letters A-W. A total of 4,853 complex (morphologically derived) forms have been identified, which can be broken down by category as follows: 2,639 nouns, 793 adjectives, 329 weak verbs and 1,092 strong verbs. The total of strong verbs dealt with in this research is 1,499 , out of which 407 correspond to simplex (morphologically underived) strong verbs. The verbs at issue can be broken down by morphological class as is shown by Appendix 1 . Out of the 407 basic strong verbs, 304 derivational paradigms have been grouped.

\section{Results of the analysis and discussion}

The 407 basic strong verbs have given rise to 304 derivational paradigms, presented by letter in table 1 , under which 4,853 derivatives have been grouped.

Table 1. Derivational paradigms by letter

\begin{tabular}{ll|ll|ll|ll|ll}
\hline B & 34 & F & 21 & L & 15 & R & 9 & W & 23 \\
\hline C & 23 & G & 24 & M & 6 & S & 78 & & \\
\cline { 1 - 5 } D & 15 & H & 27 & N & 5 & T & 5 & & \\
\cline { 1 - 5 } E & 3 & I & 1, & P & 1 & Đ & 13 & & \\
\hline
\end{tabular}

This makes an average of $c a$. sixteen derivatives and compounds per paradigm. This distribution, as was predictable, is not uniform across paradigms. To give just two examples, the paradigm of beran consists of 160 derivatives, whereas 
that of cnedan displays one only. Also, 1,092 non-basic strong verbs have been identified in the paradigms of other strong verbs, from which the former derive. The tendency has been observed throughout this analysis that strong verbs as derivatives from other strong verbs are regularly based on the infinitive form.

All in all, the four inflective forms of the verb (infinitive, preterite singular, preterite plural and past participle) constitute bases of derivation but the most productive forms are the infinitive and the past participle, the preterite singular being the least productive. The figures are presented in table 2 .

Table 2. Derivatives based on ablaut

\begin{tabular}{lr}
\hline Infinitive & 2,786 \\
\hline Preterite singular & 213 \\
\hline Preterite plural & 235 \\
\hline Past participle & 710 \\
\hline Total of derivatives based on ablaut & 3,944 \\
\hline
\end{tabular}

Nevertheless, in some cases it is the preterite singular form of the verb that provides the great majority of derivatives, as is the case of the verb blīcan 'to shine'. These figures are consistent with the evolution from stem-formation to word-formation. Indeed, the infinitive has twice as many derivatives as the preterite singular, the preterite plural and the past participle together. On the other hand, the derivatives of the preterite together with those of the past participle outnumber those of the present, which suggests that, although the typological change from stem-formation to word-formation is well under way, it is still in progress. In this respect, we concur with González Torres (2010), who addresses this question from the perspective of the existence of multiple bases of derivation and reaches the conclusion that the evolution from stem-formation to word-formation had been completed by the end of the Old English period. As is generally accepted in the field of historical linguistics, variation in the synchrony represents change in the diachrony.

Focusing on contrasts not related to ablaut, this research has yielded 854 instances, which makes an average of approximately three per derivational paradigm. The derivational paradigms of strong verbs with more than ten mutated derivatives include beran 'to bear' (65), drincan 'to drink' (40), faran 2 'to die' (33), hweorfan 'to turn' (33), cwelan 'to die' (29), slèan 1/2 'to strike' (28), brecan 'to break' (27), cuman 1/2 'to come' (23), bindan 'to bind' (22), blīcan 'to glitter' (21), brēotan 'to break in pieces' (21), būgan 'to bow' (21), gangan 1 'to go' (21), brinnan 'to burn' (19), biernan 'to burn' (15), ceeosan 'to choose' (15), fōn 'to take' (14), wrecan 'to drive' (12), būan 'to dwell' (11), calan 'to grow cool or cold' (11), grafan 'to dig' (11), rìdan 1/2 'to ride' (11), sécan 1 'to 
seek' (11) and wacan 'to awake' (11). By type of morphological contrast, the highest number of different oppositions between the base and the derivative is shown by class III of strong verbs (eo $+/ \mathrm{r} / \mathrm{h} /+$ consonant) like beorgan 'to protect', ceorfan 'to cut', hweorfan 'to turn', sweorcan 'to grow dark', weorpan 'throw' and weorpan 'become'. Figure 4 illustrates this point with hweorfan 'to turn', in whose paradigm up to six vocalic contrasts arise:

$$
\begin{aligned}
& \text { /æ/ /eo/ } \\
& \text { /e/ /eo/ } \\
& \text { hwærfan 'to turn' (hweorfan) } \\
& \text { onhwerfan 'to turn' (onhweorfan 1) } \\
& \text { /ea/ /eo/ } \\
& \text { hwearf 'exchange' (hweorfan) } \\
& \text { /i/ /eo/ } \\
& \text { behwirfan 'to exchange' (behweorfan) } \\
& \text { /ie/ /eo/ } \\
& \text { hwierfan 'to overturn' (hweorfan) } \\
& \bar{a} h w i e r f a n \text { 'to turn away' (āhweorfan) } \\
& \text { /y/ /eo/ } \\
& \text { forhwierfan 'to change' (forhweorfan) } \\
& \text { tōhwyrfan 'to overturn' (tōhweorfan) } \\
& \text { efthwyrfan 'to return' (efthweorfan) } \\
& \text { ymbhwyrft 'rotation' (ymbhweorfan) }
\end{aligned}
$$

Figure 4. Morphological contrasts in the paradigm of hweorfan

Even though the contrasts in figure 4 that do not comprise two glides (/e/ /eo/ and $/ \mathrm{i} / \sim / \mathrm{eo} /$ ) could be disregarded on the ground of alternative spelling (hwerfan and hwirfan can indeed be considered orthographic variants of hwyrfan), there remain four contrasts. This represents the maximal degree of mutation, which has been found in this research with respect to /eo/ in the strong verb base. Although more research is needed before reaching a final conclusion regarding this point, the high degree of mutation with respect to /eo/ might be related to the heterogeneous origin of the diphthong, which originates, at least, in the breaking of /e/ before /r/, /l/ and [h], as well as the back mutation of /e/.

The list of the contrasts not attributable to ablaut that constitute alternations of the type presented in figure 4 is given in figure 5 . The number in brackets corresponds to the occurrences, and there is an illustration of each:

$$
\begin{aligned}
& \text { A1 /a/ /æ/ faran } \sim \text { fær } \mathbf{( 6 3 )} \\
& \text { bacan 'to bake' bæc } 3 \text { 'baked meats' }
\end{aligned}
$$


$\mathrm{A} 1 \mathrm{R} / æ / \sim / \mathrm{a} /$ stæl $~$ stalu (24)

cwæl (pret. sg. cwelan 'to die') cwalu 'killing'

$\mathrm{A} 2$ /a/ /e/ acan ece (=PA1 land lendan) (46)

bannan 'to summon' benn 2 'edict'

A2R /e/ /a/ sendan sand (12)

wrecan 'to drive' $\sim$ forwracned 'banished'

A3 /ea/ /ie/ feallan fiell (4) feallan 'to fall' fiell 'destruction'

A3R /ie/ /ea/ mierran gemearr (15)

biernan 'to burn' bearnan 'to cause to burn'

A4a /e/ /i/ gecweden $\sim$ cwide (=PA3 segl siglan) (23)

brecan 'to break' eodorbrice 'house-breaching'

A4b /eo/ /ie/ weorpan wierp (6)

hweorfan 'to turn' ähwierfan 'to turn away'

$\mathrm{A} 4 \mathrm{bR} / \mathrm{y} / \sim$ /eo/ wyrcan $\sim$ weorc (31)

onbyrgan 1 'to eat' $\sim$ beorgan 2 'to taste'

A5 /o/ /y/ gebrocen bryce (=PA4 bold byldan) (102)

belgan 'to be or become angry' bylgan 2 'to anger'

A6 /u/ /y/ burston byrst (=PA6 lust lystan) (46)

brunen 'to burn' bryne 'burning'

$\mathrm{A} 7 / \overline{\mathrm{a}} / \sim / \overline{\mathrm{x}} / d r \bar{a} f \sim d r \overline{\mathrm{x}} f(=\mathrm{PA} 2$ lā $r \sim l \overline{\mathrm{x}} r a n)$ (56)

$b \bar{a} d$ (pret. sg. bìdan 'to stay') $\bar{a} b \bar{x} d a n$ 'to compel'

$\mathrm{A} 7 \mathrm{R} / \overline{\mathfrak{x}} / \sim / \overline{\mathrm{a}} / \mathrm{l} \overline{\mathrm{x}} r a n \sim \operatorname{la} r \mathbf{( 1 )}$

lētan 'to allow' underlâttēow 'consul'

$\mathrm{A} 8 / \overline{\mathrm{o}} / \sim / \overline{\mathrm{e}} /$ lōcian $\sim$ lèc (=PA5 blōd $\sim$ blēdan) (8)

blōtan 'to sacrifice' blēdan 'to bleed'

$\mathrm{A} 8 \mathrm{R} / \overline{\mathrm{e}} / \sim / \overline{\mathrm{o}} /$ fēdan $\sim$ fōda (12)

brēedan 1 'to produce' $\sim$ brōd 'brood'

A9 /ēa/ /īe/ hlēat hlīet (=PA8 stēam stīeman) (5)

hēawan 'to hew' hiewet 'cutting'

$\mathrm{A} 10 / \overline{\mathrm{e}} \mathrm{o} / \sim / \overline{\mathrm{e}} /$ flèotan $\sim$ flīeta (11)

flēon 'to fly from' $\sim \bar{a}$ flìegan 'to put to flight'

$\mathrm{A} 11 / \overline{\mathrm{u}} / \sim / \overline{\mathrm{y}} /$ būan $\sim b \bar{y}$ (=PA7 rūm $\sim$ rȳman) (13)

brūcan 'to brook' brȳcian 'to enjoy'

Figure 5. Alternations and occurrences

Regarding figure 5, it must be noted that the most frequent alternations are those that have /y/ as target, as is the case with A5/0/ /y/ gebrocen bryce (=PA4 bold $\sim$ byldan) and $\mathrm{A} 6 / \mathrm{u} / \sim / \mathrm{y} /$ burston $\sim$ byrst (=PA6 lust $\sim$ lystan). The alternations having /a/ as source (A1/a/ /æ/ faran fær and A2 /a/ /e/ acan ece (=PA1 
land lendan)) are also remarkably frequent. The frequency of alternations with $/ \mathrm{y} /$ as target and /a/ as source can be explained on the ground of i-mutation. Indeed, as has been shown in figure $3, \mathrm{a} /$ is the point of departure of this phenomenon (low and back, unrounded), while $/ \mathrm{y} /$ is the point of arrival (high and front, rounded). Overall, direct alternations are far more frequent than inverse ones, which is in keeping with the role of the strong verb in derivation. As a matter of fact, four reverse alternations have not been found in the corpus of analysis. This is due to the fact that the derivational paradigms have been gathered around the strong verb and the alternations in question, illustrated in figure 6, select the noun, the adjective, the verb and (far less frequently) the adverb as base of derivation:

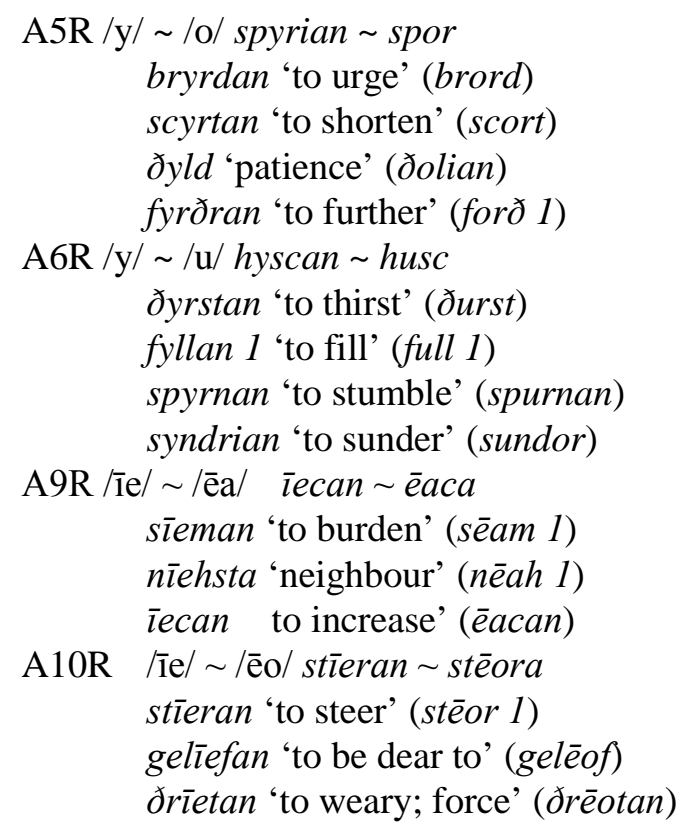

Figure 6. Bases of reverse alternations

Purely quantitative contrast, including $/ \overline{\mathrm{a}} / \sim / \mathrm{a} /$, , $/ \sim / \overline{\mathrm{e}} /$ and $/ \overline{\mathrm{o}} / \sim / \mathrm{o} /$, throw a low figure (10 occurrences) and are disregarded because mutation, which constitutes the governing principle of alternations, does not cause quantity change. The qualitative-quantitative contrasts, which evince a total of 164 occurrences, comprise the vowels and/or vocalic glides $/ \overline{\mathrm{a}} / \sim / \mathfrak{e} /, / \mathrm{a} / \sim / \overline{\mathrm{e}} /, / \mathrm{a} / \sim / \overline{\mathrm{e}} /, / \mathfrak{x} / \sim / \overline{\mathrm{a}} /$,

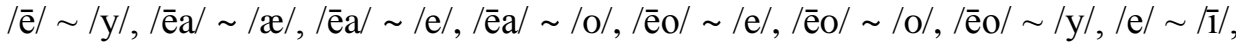
$/ \overline{\mathbf{1}} / \sim / \mathrm{e} /, / \overline{\mathbf{1}} / \sim / \mathrm{u} /, / \overline{1} / \sim / \mathrm{y} /, / \mathrm{i} / \sim / \overline{\mathrm{y}} /, / \overline{\mathrm{o}} / \sim / \mathrm{e} /$ and $/ \overline{\mathrm{u}} / \sim / \mathrm{y} /$. They have been disregarded for the same reason as purely quantitative contrasts.

Of the remaining contrasts, those in figure 7 do not conform to alternations as defined by Kastovsky (1968) but correspond to the direction of i-mutation, 
with which their ultimate motivation, as is the case with the alternations in figure 3, is phonological:

$$
\begin{aligned}
& / æ / \sim / \mathrm{e} /(\mathbf{1}) \\
& \text { stæppan 'to step' } \sim \text { insteppan 'to go in' } \\
& / \overline{\mathrm{u}} / \sim / \overline{\mathrm{y}} /(\mathbf{1 3}) \\
& \text { brücan 'to brook’ brȳcian 'to enjoy' }
\end{aligned}
$$

Figure 7. Contrasts based on i-mutation

An important group of contrasts reflects the overlapping of the result of the imutation of long and short /u/ (long and short $/ \mathrm{y} /$ ) and the long and short diphthongs /ea/ and /eo/ (long and short /ie/) as well as the West-Saxon evolution /ie/ > /i/ > /y/. They are presented in figure 8 .

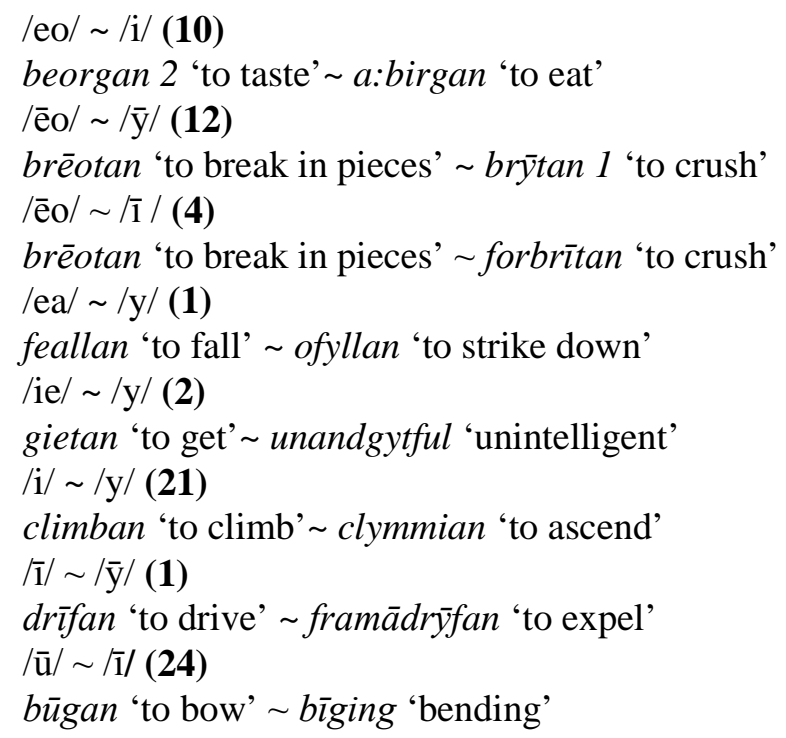

Figure 8: I-mutation and West-Saxon /ie/ > /i/ > /y/.

Although the contrasts in figure 7 and 8 were attributed to phonological evolution, this leaves us with a list of sixteen completely unpredictable contrasts, which are listed in figure 9 .

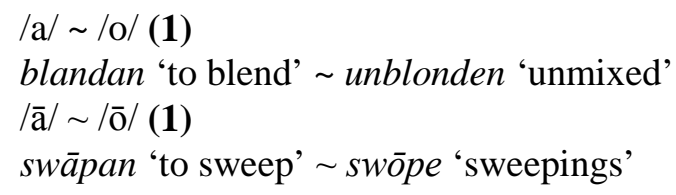




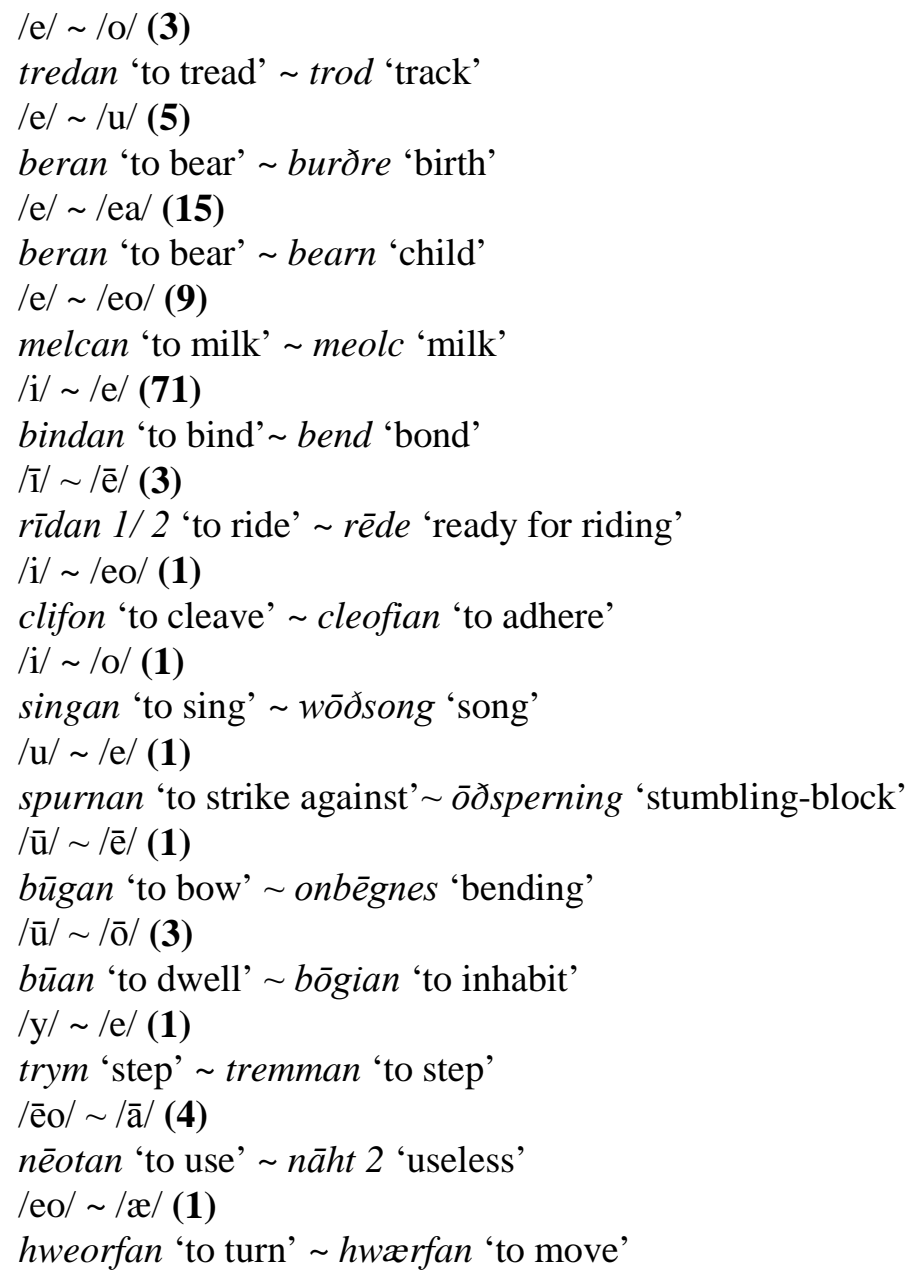

Figure 9. Unpredictable contrasts

Considering the evidence presented in figure 9, it must be accepted that the great majority of contrasts are very infrequent. Most of them present less than five occurrences and can be considered exceptional, but at least the following contrasts deserve mention: /e/ /eo/, /e/ /ea/ and /i/ /e/, which clearly stands out for quantitative reasons. In the absence of a phonological explanation, it is not unreasonable to reach the conclusion that these contrasts constitute instances of allomorphic variation that arise in lexical creation. This accords with Kastovsky's (2006: 71) remarks that the phonological conditioning of alternations is lost in diachronic evolution. 
To close this discussion, it is necessary to determine whether these instances of alternation and allomorphic variation are still within the bounds of morphology or they belong exclusively in the lexicon. Although the answer to this question largely depends on the theoretical persuasion of the researcher, it seems beyond a doubt that on the face of the evidence gathered in this research (i) there is morphological contrast between base and derivative; (ii) such a contrast is relatively recurrent; and (iii) the change in form is as a general rule paralleled by a meaning modification. On the other hand, the modification of meaning is not systematic and, moreover, is achieved mainly by other means (affixation). All in all, Old English alternations are more widespread and systematic than in the modern language, which has some fossilized alternations (Haspelmath 2002: 193). García García (2012: 26) holds that the alternations applying to jancausative verbs are lexical because they are lexically conditioned and ready to be levelled out. The solution that we propose in this respect is that the phonologically motivated alternations discussed in this paper are morphological due to the morphological contrast they involve, their relative frequency and, above all, because they are related to the ablaut system of the strong verb. As for allomorphic variation, this phenomenon represents a consequence of the variable character of the bases of Old English morphology and therefore can be considered morphological. Eventually, with the change from variable base morphology into invariable base morphology, the partial replacement of the strong conjugation with the weak conjugation and the associated loss of many strong verbs, allomorphic variants and alternations must have become purely lexical.

\section{Conclusion}

This article has analyzed 304 derivational paradigms based on strong verbs, under which 4,853 derivatives have been grouped, and found that 3,944 of them display root vowels based on the ablaut pattern of the corresponding strong verb. The vowel of the infinitive appears in approximately one half of the derivatives, while the other half display the same vowel as the past participle more frequently than that of the preterite. This research has also yielded 854 instances of contrast between the strong verb and its derivatives that cannot be attributed to the ablaut pattern of the verb, 478 of which qualify as phonologically motivated morphological alternations. The most frequent alternations are those that have /a/ as source and those with /y/ as target, because /a/ is the point of departure of $\mathrm{i}$-mutation and $/ \mathrm{y} /$ its point of arrival. Direct alternations are far more frequent than inverse ones given the central role played by the strong verb in derivation. Even a very conservative approach has identified sixteen completely unpredictable contrasts, thus instances of allomorphic variation, of which /e/ /eo/, /e/ /ea/ and /i/ /e/ are relatively frequent. The unpredictability and asys- 
tematicity of these contrasts indicate a higher degree of variation than a productive procedure can possibly manage. This is so because alternations are recurrent and contribute to the systematic nature of language. However, once the phonological system in which alternations originated no longer exists and the oppositions that gave raise to alternations no longer hold, alternations become morphological. This means that they mark a formal contrast between bases and derivatives of synchronically or etymologically related paradigms, but that such a contrast cannot be repeated productively. Consequently, new unmotivated contrasts, which have been described in this work as allomorphic variants, find their way into the lexicon.

\section{REFERENCES}

Campbell, Alistair. 1959. Old English grammar. Oxford: Oxford University Press.

Dik, Simon. 1997a. The theory of functional grammar. Part 1: The structure of the clause. Berlin: Mouton de Gruyter. Edited by Kees Hengeveld.

Dik, Simon. 1997b. The theory of functional grammar, Vol. 2: Complex and derived constructions. Berlin: Mouton de Gruyter. Edited by Kees Hengeveld.

Foley, William A. \& Robert D. Van Valin Jr. 1984. Functional syntax and Universal Grammar. Cambridge: Cambridge University Press.

García García, Luisa. 2012. Old English jan-causatives: Between grammar and lexicon. In Javier Martín Arista, Roberto Torre Alonso, Andrés Canga Alonso \& Inmaculada Medina Barco (eds.), Convergent approaches to mediaeval English language and literature, 15-28. Newcastle: Cambridge Scholars.

González Torres, Elisa. 2010. The bases of derivation of Old English affixed nouns: Status and category. Studia Anglica Posnaniensia 46(2). 21-43.

Haselow, Alexander. 2011. Typological changes in the lexicon. Analytic tendencies in English noun formation. Berlin: Mouton de Gruyter.

Haspelmath, Martin. 2002. Understanding morphology. London: Hodder Education.

Hinderling, Robert. 1967. Studien zu den starken Verbalabstrakten des Germanischen. Berlin: Walter de Gruyter.

Hogg, Richard M. 1992. Phonology and morphology. In Richard M. Hogg (ed.), The Cambridge history of the English language I. The beginnings to 1066, 67-167. Cambridge: Cambridge University Press.

Jensen, John. 1913. Die I. und II. Ablautsreihe in der ae. Wortbildung. Kiel: H. Fiencke.

Kastovsky, Dieter. 1968. Old English deverbal substantives derived by means of a zero morpheme. Tübingen: Eberhard-Karls-Universität.

Kastovsky, Dieter. 1986. Deverbal nouns in Old and Modern English: From stem-formation to word-formation. In Jacek Fisiak (ed.), Historical semantics - historical word formation, 221-261. Berlin: Mouton de Gruyter.

Kastovsky, Dieter. 1989. Morphophonemic alternations and the history of English: Examples from Old English. In Manfred Markus (ed.), Historical English. On the occasion of Karl Brunner's 100th birthday, 112-123. Innsbruck: Universität. 
Kastovsky, Dieter. 1990. The typological status of Old English word formation. In Silvia M. Adamson, Vivien A. Law, Nigel Vincent \& Susan Wright (eds.), Papers from the $5^{\text {th }}$ International Conference on English Historical Linguistics, 205-224. Amsterdam: John Benjamins.

Kastovsky, Dieter. 1992. Semantics and vocabulary. In Richard M. Hogg (ed.), The Cambridge history of the English language I: The beginnings to 1066, 290-408. Cambridge: Cambridge University Press.

Kastovsky, Dieter. 2005. Hans Marchand and the Marchandeans. In Pavol Stekauer \& Rochelle Lieber (eds.), Handbook of word-formation, 99-124. Dordrecht: Springer.

Kastovsky, Dieter. 2006. Typological changes in derivational morphology. In Ans van Kemenade \& Bettelou Los (eds.), 151-177. The handbook of the history of English. Oxford: Blackwell publishing.

Lass, Roger. 1994. Old English. A historical linguistic companion. Cambridge: Cambridge University Press.

Lindemann, John William Richard. 1970. Old English preverbal ge-: Its meaning. Charlottesville: Virginia University Press.

Mailhammer, Robert. 2007. The Germanic strong verbs. Foundations and development of a new system. Berlin: Mouton de Gruyter.

Martín Arista, Javier. 2008. Unification and separation in a functional theory of morphology. In Robert D. Van Valin Jr. (ed.), Investigations of the syntax-semantics-pragmatics interface, 119-145. Amsterdam: John Benjamins.

Martín Arista, Javier. 2009. A typology of morphological constructions. In Stuart Christopher Butler \& Javier Martín Arista (eds.), Deconstructing constructions, 85-115. Amsterdam: John Benjamins.

Martín Arista, Javier. 2010a. Lexical negation in Old English. NOWELE (North-Western European Language Evolution) 60/61. 89-108.

Martín Arista, Javier. 2010b. Adjective formation and lexical layers in Old English. English Studies 92(3). 323-334.

Martín Arista, Javier. 2011a. Morphological relatedness and zero alternation in Old English. In Pilar Guerrero Medina (ed.), Morphosyntactic alternations in English. Functional and cognitive perspectives, 339-362. Sheffield: Equinox.

Martín Arista, Javier. 2011b. Projections and constructions in functional morphology: The case of HRĒOW. Language and Linguistics 12(2). 393-425.

Martín Arista, Javier. 2012. The Old English prefix ge-: A panchronic reappraisal. Australian Journal of Linguistics 32(4). 411-433.

Martín Arista, Javier. 2013. Recursivity, derivational depth and the search for Old English lexical primes. Studia Neophilologica 85(1). 1-21.

Martín Arista, Javier \& Francisco Cortés Rodríguez. From directionals to telics: Meaning construction, word-formation and grammaticalization in Role and Reference Grammar. In María Ángeles Gómez González, Francisco Ruiz de Mendoza Ibáñez \& Francisco Gonzálvez García (eds.), Form and function in language: Functional, cognitive and applied perspectives. Amsterdam: John Benjamins. Forthcoming.

Palmgren, Carl. 1904. English gradation-nouns in their relation to strong verbs. Uppsala: University of Uppsala.

Ringe, Don. 2006. From Proto-Indo-European to Proto-Germanic. A linguistic history of English. Volume I. Oxford: Oxford University Press. 
Schuldt, Claus. 1905. Die Bildung der schwachen Verba im Altenglischen. Kiel: Verlag von Robert Cordes.

Trips, Carola. 2009. Lexical semantics and diachronic morphology. The development of -hood, -dom and -ship in the history of English. Tübingen: Max Niemeyer Verlag.

Van Valin, Robert D. Jr. 2005. Exploring the syntax-semantics interface. Cambridge: Cambridge University Press.

Van Valin, Robert D. Jr. \& Randy J. LaPolla. 1997. Syntax: Structure, meaning and function. Cambridge: Cambridge Univeristy Press. 


\section{APPENDIX 1 \\ Basic strong verbs by morphological class}

Class I: bìdan 'to stay', bìtan 'to bite', cīfan 'to quarrel', cìnan 'to gape', clīfan 'to cleave', cwìnan 'to waste', drīfan 'to 'drive', drītan 'cacare', dwinnan 'to waste away', figan 'to be or become an enemy', flitan 'to strive', ginan 1 'to yawn', gl̄̄ædan 'to cause to slip', glīdan 'to glide', gnīdan 'to rub', grīpan 'to seek', grīsan 'to shudder', hlìdan 'to come forth', hlïfan 'stand out', hlìgan 'to attribute', hnīgan 'to bow', hnītan 'to thrust', hrinnan 'to touch', hwīnan 'to hiss', lēon 'to lend', lìðan 1 'to go to', lìðan 2 'to be bereft of', lìðan 4 'to arrive', lïfan 4 'to remain', mìðan 'to hide', miggan 'to make water', nīpan 'to grow dark', rìdan 1 'to ride', rìdan 2 'to seize', rīsan 1 'to rise', rìsan 2 'to seize', scīnan 1 'to shine', scìnan 2 'to shine upon', scītan 'to flourish', scrìðan 'to go', scrīban 'to shrive', sēon 2 'to strain', sīcan 1 'to sigh', sìgan 1 'to sink', slìðan 'to injure', slìdan 'to slide', slīfan 1 'to slive', slīpan 'to slip', slìtan 'to slit', smìtan 'to smear', snīðan 'to cut', snīcan 'to sneak along', spīwan 'to spit', stīgan 'to move', strīcan 'to stroke', strīdan 'to stride', swìcan 'to wander', swîfan 'to revolve', têon 2 'to accuse', pinnan 'to grow moist', pwìtan 'to cut', pwīnan 'to decrease', wīcan 'to yield', wigan 'to make war', wìtan 'to guard', wlìtan 'to gaze', wrēon 'to cover', wrìtan 'to write'.

Class II: bēdan 'to command', bèodan 'to command', brēoðan 'to decay', brēotan 'to break in pieces', brēowan 'to brew', brūcan 'to brook', cēosan 'to choose', cēowan 'to chew', clēofan 'to cleave', crēopan 'to creep', crüdan 'to press', drēogan 'to do', drēopan 'to drop', drēosan 'to fall', düfan 1 'to dive', düfan 2 'to sink', flēogan 'to fly', flēon 'to flee', flēotan 'to float', freeosan 'to sneeze', frèosan 'to freeze', gēatan 'to say yea', gèopan 'to take in', gēotan 1 'to pour', grēosan 'to frighten', greeotan 'to cry', hlēotan 'to cast lots', hrēoðan 'to adorn', hrēodan 'to adorn', hrēosan 'to fall', hrēowan 'to affect one with regret', hrütan 'to make a noise', lèodan 'to spring up', lēogan 'to lie', lücan 1 'to lock', lūcan 2 'to pluck out', lūtan 1 'to bend', lütan 2 'to lay down', nēopan 'to overwhelm', nēosan 'to search out', nēotan 'to use', rēocan 1 'to emit vapour', rēodan 'to redden', rēofan 'to break', rēosan 'to fall', sceeotan 'to shoot', scūdan 'to run', scüfan 'to shove', sêcan 1 'to search for', sēocan 1 'to search for', sēoðan 'to seethe', smēocan 'to smoke', smügan 'to creep', snēowan 'to hasten', sprütan 'to sprout', strūdan 'to ravage', sūcan 'to suck', sūgan 'to suck', sūpan 'to sip', tēon 1 'to pull', prēotan 'to vex'.

Class III: belgan 'to be or become angry', beorcan 'to bark', beorgan 1 'to save', beorgan 2 'to taste', berstan 'to break', biernan 'to burn', bindan 'to bind', blinnan 'to cease', brēdan 1 'to produce', brēdan 2 'to move quickly', bregdan 1 'to shake', bregdan 2 'to scheme', bringan 'to bring', brinnan 'to burn', ceorfan 'to cut', ceorran 1 'to creak', climban 'to climb', clingan 'to stick together', crimman 
'to cram', crincan 'to yield', cringan 'to die', delfan 'to delve', deorfan 'to labour', fêolan 'to cleave', feohtan 1 'to fight', feohtan 2 'to gain by fighting', findan 'to find', frignan 'to inquire', gieldan 'to yield', giellan 'to yell', gielpan 'to boast', ginnan 'to begin', grimman 'to rage', grindan 'to grind', gringan 'to sink down', gyrran 'to sound', helpan 'to help', hlimman 'to sound, resound, roar, rage', hrimpan 'to wrinkle', hrindan 'to thrust', hweorfan 'to turn', iernan 1 'to run', iernan 2 'to get to', limpan 'to happen', linnan 'to cease', melcan 'to milk', meltan 1 'to melt', rinnan 1 'to run', rinnan 2 'to blend', scelfan 'to shake', sceorfan 1 'to scarify', sceorfan 2 'to scrape', sceorpan 'to gnaw', sciellan 'to sound', scrimman 'to shrink', scrincan 'to contract', scringan 'to shrivel up', seorðan 'to lie with', sincan 1 'to sink', singan 'to sing', sinnan 'to meditate upon', slincan 'to slink', slingan 'to worm', smeortan 'to smart', sneorcan 'to dry up', spinnan 'to spin', springan 'to jump', sprintan 'to emit', spurnan 'to skick', steorfan 'to die', stincan 1 'to stink', stincan 2 'to smell', stingan 1 'to sting', swellan 'to swell', sweltan 'to die', sweorcan 'to grow dark', sweorfan 'to file or grind away', swimman 'to swim', swincan 'to labour', swindan 'to vanish', swingan 1 'to beat', teldan 'to spread a covering', tingan 'to press against', tringan 'to press', pindan 'to swell', pringan 'to crowd', printan 'to swell', weorðan 'to become', windan 'to wind', winnan 1 'to labour', winnan 2 'to conquer', wringan 'to wring', wurpan 'to throw'.

Class_IV: beran 'to bear', brecan 'to break, cuman 1 'to come', cuman 2 'to come together', cwelan 'to die', dwelan 'to be led into error', gelan 'to pour', helan 'to conceal', hlecan 'to cohere', hwelan 'to roar', neoman 'to take', niman 1 'to take', niman 2 'grasp', scieran 'to cleave', stelan 'to steal', striman 'to resist', striman, swelan 'to burn', teran 'to tear', pweran 'to stir', pwerian 'to soften'.

Class_V: biddan 1 'to ask', biddan 2 'to beg', cnedan 'to knead', cweðan 'to say', drepan 'to strike', etan 1 'to eat', etan 2 'to eat together', fêon 'to rejoice', fnēsan 1 'to pant', fretan 'to devour', giefan 'to give', gietan 'to get', lesan 'to collect', licgan 'to lie', metan 'to measure', nesan 'to escape from', plēon 'to expose to danger', repan 'to reap', screpan 'to scrape', sēon 1 'to see', sēon 3 'to provide', sittan 1 'to sit', sittan 2 'to finish', sprecan 1 'to speak', sprecan 2 'to agree', stecan, swefan 'to sleep', tredan 'to tread', wefan 'to weave', wegan 1 'to carry', wegan 2 'to fight', wrecan 'to drive'.

Class VI: bacan 'to bake', calan 'to grow cool', dragan 'to drag', faran 1 'to set forth', faran 2 'to die', fleean 'to flay', galan 'to sing', gnagan 'to gnaw', grafan 'to dig', hladan 'to lade', hliehhan 'to laugh', sacan 'to struggle', scacan 'to shake off', scafan 'to shave', sceacan 'to shake', scieppan 'to create, slēan 1 'to strike', slēan 2 'to strike down', spanan 'to draw on', stæppan 'to step', standan 'to stand', swerian 'to swear', pwēan 'to wash', wacan 'to awake', wadan 'to wade', wascan 'to wash'. 
Class VII: bannan 'to summon', bēatan 'to beat', blāwan 1 'to blow', blāwan 2 'to kindle', blandan 'to blend', blōtan 'to sacrifice', blōwan 1 'to blow', būan 'to dwell', būgan 1 'to bow', clāwan 'to claw', cnāwan 'to know', crāwan 'to crow', dèagan 'to dye', éacan 'to increase', éadan 'to give', fealdan 'to fold', feallan 'to fall', flowwan 1 'to flow', flōwan 2 'to overflow', fōn 'to take', gangan 1 'to go', gangan 2 'to observe', glōwan 'to glow', grōwan 'to grow', hätan 'to command', hèawan 'to hew', hēofan 'to lament', healdan 'to hold', hlēapan 'to leap', hlowwan 'to low', hōn 1 'to suspend', hrōpan 'to shout', hwātan, hwōpan 'to threaten', hwōsan 'to cough', lācan 'to move up and down',

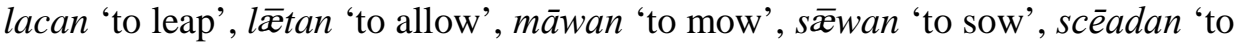
divide', sealtan 2 'to salt', spannan 'to join', spōwan 'to succeed', stealdan 'to possess', swäfan, swāpan 'to sweep', swōgan 'to sound', prāwan 'to turn',

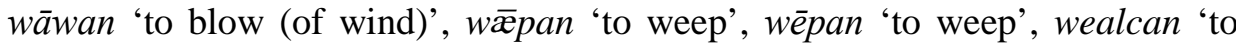
move round', wealdan 'to rule', weallan 'to be agitated', wealtan, weaxan 1 'to wax', wrōtan 'to root up'. 